\title{
Social Protection in Health: Characteristics and Coverage of Health Insurance Programme in Nepal
}

\author{
Geha Nath Khanal ${ }^{*}$, Bhagawan Regmi ${ }^{2}$ \\ ${ }^{1}$ Save the Children, Nepal \\ ${ }^{2}$ Health Insurance Board, Government of Nepal \\ ${ }^{*}$ Corresponding author's email: khanalg@outlook.com \\ DOI: https://doi.org/10.3126/jsp.v1i0.38209
}

\section{A R T I C L E I N F O}

Article history:

Received 03 Oct. 2020

Accepted 14 Nov. 2020

Keywords:

Coverage

Health insurance

NIHP

Policy

Political commitment

Social protection

\section{A B S T R A C T}

The agenda of social protection has become very popular in
recent years. Several social protection programs in healthcare are designed to increase the healthcare coverage, ensure financial protection and enhance the scope and quality of services and access to medicines which ultimately paves the way for universal health coverage. The national health insurance programme (NHIP) is one of the approaches implemented in Nepal to cover healthcare expenditure. This paper discusses the gradual development of the health insurance programme in Nepal and the key features of NHIP that have been implemented since 2016. It further highlights the implementation status of NHIP, the milestones it covered, and the role of political parties in implementing NHIP in Nepal. Furthermore, the paper discusses the challenges associated with enrollment of formal and non-formal sectors, the mismatch between geographical coverage and the number of service contact points, and commitment from the political parties for effective implementation of NHIP. It seeks major implementation reforms to ensure effective implementation of NHIP.

\section{Introduction}

The World Health Organization advocates for Universal Health Coverage (UHC) that aims to ensure health care services to all people, even those facing financial hardship (WHO \& The World Bank, 2017). The UHC commits to increase healthcare coverage, ensure financial protection, and enhance the scope and quality of services and access to medications. This requires adequate fiscal space in healthcare expenditure, which is a big challenge in resource-constrained countries that often have to compromise their healthcare system. Annually, almost 100 million people worldwide are pushed into poverty because 
of healthcare related expenses (ILO, 2020). Moreover, almost 800 million people utilize one-tenth of their household budgets on healthcare expenses and most of these are from low and middle-income countries (ILO, 2020).

Social protection in a broad sense consists of policies and programs aiming to reduce poverty and deprivations that provide adequate security to the basic minimal livelihood of citizens (Drucza, 2018). Welfare states often commit to protecting their population from such catastrophic expenditure by several social protection programs. However, low and middle-income countries are much affected by the cost of healthcare since there is not much variation in the cost of medicine and services across the world. Social protection in health (SPH) emphasises the importance of explicit societal guarantee for access to healthcare services (ILO, 2002). The ultimate purpose of social protection is to expand human capabilities, which allows citizens to live a good life (Anand et al., 2005). The investment in human capital will ensure the quality of life as its return. This requires a comprehensive framework coupled with three major dimensions namely protection against health risk, patient protection, and financial protection along with several associated interventions (Knaul et al., 2012).

$\mathrm{SPH}$ is an arrangement that safeguards income and financial support in case of illness and ensures that all people in need have access to adequate and quality healthcare (Michielsen et al., 2010). It aims to protect an individual from any kind of risk that may arise during the utilization of healthcare services and provides the opportunity from dependency to productive livelihood through various risk management mechanisms. Strengthening such capabilities allow citizens to fully enjoy their economic, social, and cultural rights (Knaul et al., 2012). Moreover, this helps to ensure inviolable rights of the citizen which promotes individual and population wellbeing (Devereux \& SabatesWheeler, 2007). However, effective access to quality healthcare remains uncovered in most resource-constrained countries. The healthcare services in these countries are not only compromised in terms of its quality, but are also expensive where individuals have to bear all the expenses for the service by themselves. Difficulty in selecting the alternatives between whether to seek healthcare treatment or get trapped in a vicious cycle of poverty that arises as a result of expensive healthcare services (Michielsen et al., 2010).

$\mathrm{SPH}$ is central to reaching the objective of UHC, which emphasises the importance of financial protection and effective access to quality healthcare services. It is an integral component of a comprehensive social protection system to ensure health as a human right through the mechanism of universal access to an affordable, quality, and adequate healthcare services. In Nepal, Outof-pocket expenditure in healthcare is about 55 per cent (MoHP, 2018), which has been a major burden to poor households. Hence, $\mathrm{SPH}$ is crucial, bearing the expenses for own health care may push an individual below the poverty line (Tejuoso et al., 2018). Nepal has adopted social health insurance as SHP, where the poor and targeted populations are provided with subsidies for getting enrolled in the National Health Insurance Programme (NHIP). Based on the available literature and secondary data, this paper aims to explore the health insurance efforts of both government and private sectors in Nepal with a special focus on the health insurance programmes and its historical development, policy provisions, and concerns of political parties and increasing population and area coverage in Nepal.

\section{Methods and Materials}

This paper is primarily based on review of published literature and reports, and acts and 
policies pertinent to health sector in Nepal. We categorised the historical development into two parts; the community-based microhealth insurance (CBMHI) programme and the NHIP that was implemented after 2016. We conducted a document review to explore the historical development of CBMHI in Nepal. Review of available literature to explore the efforts made by non-government and government sectors in implementing health insurance programme in the country was conducted. Furthermore, we reviewed the key features of NHIP, its geographical coverage, and the status of social protection in health through NHIP. The features of NHIP were assessed through a critical review of Health Insurance Policy, 2014, Health Insurance Act, 2017 and Health Insurance Regulation, 2019 (Government of Nepal, 2019), while the coverage data were assessed from the Health Insurance Board (Health Insurance Board, 2020).

\section{Results and Discussion}

\subsection{Social protection in health sector in Nepal}

The Universal Declaration of Human Rights (UDHR) has indicated that an individual has the right to social security and live a standard life for his/her health (United Nations, 1948). Being one of the signatory nations of UDHR, Nepal is also obliged to formulate appropriate policies for social protection to fulfill these rights. The provision of social protection to the general population in Nepal was started following the restoration of democracy in 1990. The multi-party democracy provided space for raising voice for rights of social protection from the state. Consequently, several legal reforms were made, that paved way for developing provisions on social protection. For instance, the Children's Act of 1992 had the provision of SPH for mothers and children. The Act directed the government to make necessary arrangements for proper healthcare for pregnant and recently delivered mothers (Government of Nepal, 1992). Likewise, the Social Welfare Act, 1992 allowed the Government to operate special welfare programs for the children, old-aged and helpless people. Moreover, the Civil Service Act, 1993 had a provision of monthly pension entitled to those serving 20 years in the public service. Consequently, several other laws like the Labour Act, Trade Union Act, the Civil Servant Act, and Senior Citizen Act, were endorsed which had some provision for providing social protection to the citizens (Niroula, 2018). However, there were no special social protection programmes except for privileged minorities employed in the security or civil service in the form of pension until 1994 (Drucaz, 2016). The Unified Marxist Leninist Party (UML) formally announced the social protection cash transfer programme through the senior citizen programme in 1994, when the party formed the minority government. This paved the way for social protection in the health sector in Nepal.

Several interventions are being made for social protection on health in Nepal. Firstly, protection against health risk has been done through interventions like surveillance, preventive, and regulatory activities, although these are not adequate. Likewise, there is a provision of quality assurance mechanisms in the delivery of healthcare services, however, the implementation has not been effective. Finally, financial protection against economic consequences of disease and injury has been done through various cost-sharing interventions like free basic health services, conditional cash transfer mechanisms, subsidies to disadvantaged and minority groups, and implementation of a national health insurance programme. However, these interventions are implemented rather on a 
fragmented basis (Witter et al., 2011; Knaul et al., 2012; Khanal, 2018; Ranabhat et al., 2019). The major actions and the guiding policy instruments for social protection in health in Nepal is presented in Figure 1. scheme covered both organised (cooperatives, business groups) and unorganised (such as farmers and self-employed) groups. This however was unable to expand due to the adverse selection by chronic patients for

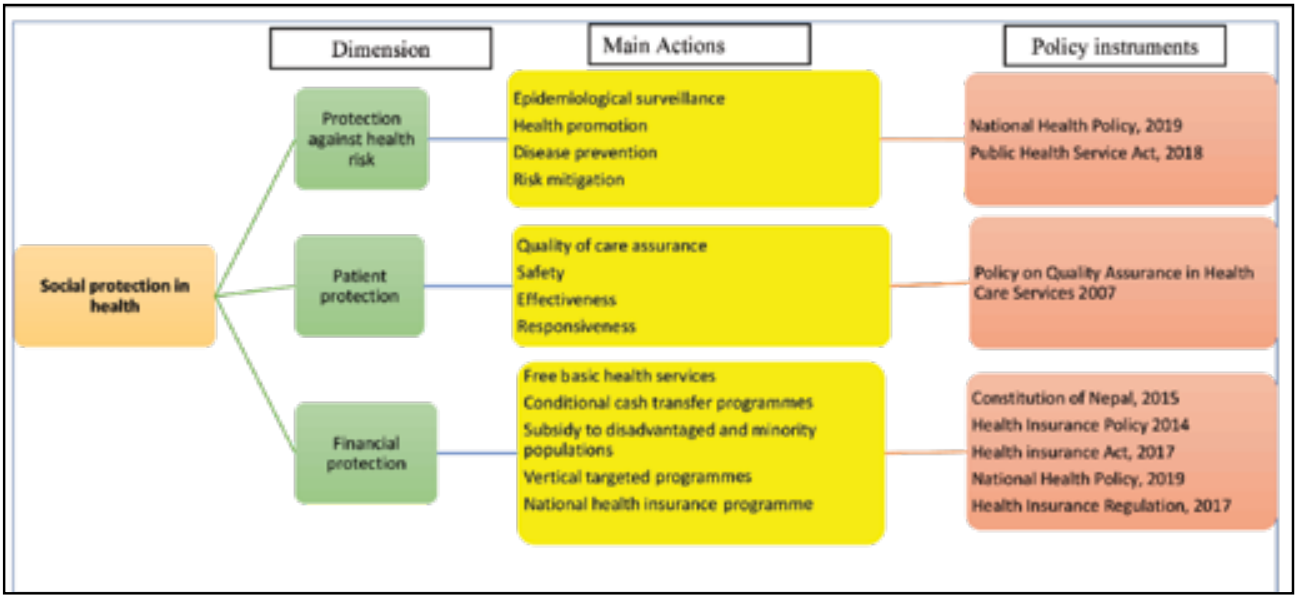

Figure 1: Dimension of social protection in health and its policy instruments in Nepal (Adapted from Knaul et al., 2012)

\subsection{Health insurance efforts in government and non-government setup}

Nepal has a long history of private, non-profit insurance schemes initiated with the support of external development partners. Lalitpur Medical Insurance scheme for instance was the first insurance scheme initiated in 1976 by the United Mission to Nepal (UMN). The scheme mostly covered the cost of essential drugs and registration and, therefore, was treated as an insurance scheme for essential medicines. After handing over the scheme to the relevant facility management committees in the 1980s, some of the schemes failed due to political differences and lack of commitment (Stroermer et al., 2012).

In 2000, BP Koirala Institute of Health Science (BPKIHS) started health insurance that covered urban and rural populations, offering the same benefits package at different premium rates. The enrollment, and over-utilisation of services by the insured population (moral hazard). This resulted in the fiscal deficit which arose mainly due to high reimbursement and low premium collection (Stroermer et al., 2012). Similarly, Primary Health Care and Resource Center in Chapagaun, Lalitpur, and Karuna Foundation Nepal support schemes in Sunsari and Rasuwa districts were examples of few other similar schemes. Likewise, Save the Children with support from MISEROER supported Saubhagya Laghu Swastha Surachhya Kosh in Dhading and Sanjeevani Health Insurance Scheme in Banke district.

The Government of Nepal announced to implement a communitybased health insurance (CBHI) programme in 2003/04. Following this announcement, the Ministry of Health and Population (MoHP) implemented CBHI schemes in two primary health care centers, Mangalabare primary health care centers (PHCC) (in Morang district) and Dumkauli PHCC (in 
Nawalparasi district), as pilot programmes. Later, in 2005/06, the MoHP decided to expand the programme to four more districts - Udayapur (Katari PHCC), Rautahat (Chandranigahapur PHCC), Dang (Lamahi PHCC), and Kailali (Tikapur PHCC). Later in 2006, the Free Health Care programme was introduced all over the country and covered almost the same benefits package as the $\mathrm{CBHI}$ scheme which resulted in a serious setback in the later scheme (Stroermer et al., 2012).

Earlier, Health Economics and Financing Unit (HEFU) was established under MoHP in 2002 that was responsible for analysing the Health Public Expenditure Review and National Health Accounts. Later in 2012, HEFU initiated an assessment of CBHI. This assessment was done to assess the contribution of $\mathrm{CBHI}$ and its performance. The assessment further sought recommendations for further improvement of CBHI schemes within the context of existing healthcare financing landscape and policy developments (Stroermer et al., 2012). The review suggested a financially viable broader health insurance programme at the national level with wide population coverage, providing equitable protection to the poor and marginalised population (Stroermer et al., 2012).

Based on the recommendations of the CBHI programme, the National Health Insurance Policy was formulated in 2014 to ensure universal health coverage by increasing access to and utilisation of necessary quality healthcare services by removing financial barriers. Furthermore, the Constitution of Nepal, 2015 ensured free basic healthcare services and committed to implementing the health insurance programme to provide the services beyond basic healthcare services (Government of Nepal, 2015). Consecutively, Social Health Security Programme Operating Rules was endorsed in 2015 to implement NHIP. Later, a separate Health Insurance Act was endorsed in 2017, which aimed to protect the citizen's right to obtain quality healthcare services by providing financial protection through pre-payment mechanisms. This would make the health expenditure productive and reduce financial risk in accessing quality healthcare services (Government of Nepal, 2017). Similarly, the Health Insurance Regulation was endorsed in 2019 (Government of Nepal, 2019) which delineates the Health Insurance Act 2017.

\subsection{Political commitment and some milestones}

Following the advent of multi-party democratic system in 1990, there was a political priority in implementing the social protection programmes. One of the major factors behind this political commitment could be the political capital of such programmes. It is assumed that the social protection programme not only gains electoral votes but also supports in gaining popularity among the political parties. The political parties capitalise such social protection programmes in gaining popular votes during the elections. For instance, the Communist Party Nepal Unified Marxist Leninist (CPN UML) has been capitalising the political agenda of social protection in every election after 1994 claiming to be the pioneer of such programme (Drucza, 2018) The provision of monthly Nepalese Rupees (NRs) 100 allowance to senior citizens implemented during its minority government is still immensely popular and every subsequent government has been continuing it for its social merits and political capital (Drucza, 2018).

There was several milestones right from the inception to implementation of the health insurance programme in Nepal in the last decade. This took place despite frequent changes in the political leadership during the transitional and constitution-making period. For instance, seven governments were formed between 2013 and 2018. Furthermore, the health ministers had different political 
ideologies than their Prime Minister. Despite such political environment, there were not any countervailing views regarding the health insurance programme between the executive head and the Health Minister that ultimately helped to gain strong political commitment from all the political parties. Table 1 shows the political leadership and their roles in different stages of the health insurance policy.

The Constitution of Nepal, 2015 has clearly stated the provision of social protection and social security as fundamental rights, that can be ensured through the necessary legal provisions for protection, empowerment, or development of the needy, indigent, incapacitated, and helpless citizens (Government of Nepal, 2015). To fulfill this constitutional provision, several social security programmes are being implemented in Nepal. Furthermore, capitalising on social protection programmes by all the political parties has been reflected in their political manifesto. For instance, the ruling Nepal Communist Party (NCP) have expressed their commitment to increase the senior citizens' allowance from NRs 2,000 to 5,000

Table 1: Health insurance milestones and political leadership (2013-2018)

\begin{tabular}{|c|c|c|c|}
\hline Year & $\begin{array}{c}\text { Government } \\
\text { leadership }\end{array}$ & $\begin{array}{l}\text { Political affiliation } \\
\text { of health minister }\end{array}$ & Major actions \\
\hline 2013 & $\begin{array}{l}\text { Unified Maoist } \\
\text { Center }\end{array}$ & Sadbhawana Party & $\begin{array}{l}\text { - Selected five districts (Kailali, Ilam, } \\
\text { Baglung, Banke, and Sarlahi) for the } \\
\text { first phase of implementation }\end{array}$ \\
\hline 2014 & Non-political & Non-political & $\begin{array}{l}\text { - Formed a committee to draft Health } \\
\text { Insurance Policy } \\
\text { - Established the National Social Health } \\
\text { Insurance Unit }\end{array}$ \\
\hline 2015 & Nepali Congress & CPN UML & $\begin{array}{l}\text { - Endorsed Social Health Security } \\
\text { (Formation Order) } \\
\text { - Establishment of Social Health } \\
\text { Security Development Committee }\end{array}$ \\
\hline 2016 & CPN UML & $\begin{array}{l}\text { Madheshi People's } \\
\text { Right Forum (MPRF) } \\
\text { Democratic }\end{array}$ & $\begin{array}{l}\text { - Launched health insurance scheme in } \\
\text { three districts (Kailali, Baglung, and } \\
\text { Ilam) }\end{array}$ \\
\hline \multirow{2}{*}{2017} & Maoist Center & Nepali Congress & $\begin{array}{l}\text { - Tabled Health Insurance Bill in the } \\
\text { Legislative Parliament }\end{array}$ \\
\hline & Nepali Congress & Unified Maoist Center & - Endorsed Health Insurance Bill \\
\hline 2018 & $\begin{array}{l}\text { Nepal Communist } \\
\text { Party }\end{array}$ & Communist & $\begin{array}{l}\text { - Full subsidies to the elderly population } \\
\text { aged } 70 \text { and above } \\
\text { - Full subsidies to ultra-poor, severely } \\
\text { disabled, and the patients with MDR } \\
\text { Tuberculosis, Leprosy HIV and AIDS } \\
\text { - Half subsidies to the families of Female } \\
\text { Community Health Volunteers }\end{array}$ \\
\hline
\end{tabular}

* CPN UML: Communist Party of Nepal United Marxist Leninist

** The Unified Maoist Centre and CPN UML merged and formed Nepal Communist Party (NCP) in 2017 
through their political manifesto during the recent election (Communist Party of Nepal, 2017). However, it later declared to provide a free health insurance programme for the elderly population comprising of benefits up to NRs 100,00 instead of such allowances (Government of Nepal, 2018a). Likewise, some provincial and local governments have committed to bear the cost of health insurance premiums of the targeted population. With this, not only have they expressed their political commitment, but this also demonstrates their agenda for ensuring political capital through SPH.

\subsection{Major features of NHIP}

of Nepal, 2017) and its Regulation, 2019 (Government of Nepal, 2019). The silent features of NHIP are presented in Table 2.
The National Health Insurance Programme (NHIP) was introduced in April 2016 (Ghimire et al., 2019). In the beginning, family with five members had to pay NRs 2,500 as a contribution and was eligible for health expenses up to NRs 50,000. The programme covered the cost for Out-Patient Department (OPD) and 66 types of illness. This benefit package has been gradually increased over time. Currently, 1,133 types of medicine are included in the NHIP benefit package. Furthermore, the recent Health Insurance Regulation, 2019 has increased the initial contribution amount from NRs 2500 to 3,500 for a family as well as expanded the benefit package from NRs 50,000 to 100,000 (Government of Nepal, 2019).

The NHIP of Nepal is guided by the Health Insurance Act, 2017 (Government

Table 2: Features of health insurance programme of Nepal

\begin{tabular}{|c|c|}
\hline Feature & Description \\
\hline Funding & $\begin{array}{l}\text { - Government subsidies (federal, provincial, and local) } \\
\text { - Membership contribution } \\
\text { - Contribution from national institutions, organizations, and individuals } \\
\text { - Contribution received from foreign governments, international organizations, or } \\
\text { individuals } \\
\text { - Earnings from any sources }\end{array}$ \\
\hline Enrollment & $\begin{array}{l}\text { - Mandatory for all citizens } \\
\text { - Parents/guardians should enroll the newborn, children, elderly and disabled } \\
\text { population } \\
\text { - Managers/owners should enroll old age home, orphanage, and juvenile house } \\
\text { group members } \\
\text { - Employee to be enrolled by their institutions assuming such institutions as a } \\
\text { family } \\
\text { - Poor and targeted groups are to be ensured by the Government of Nepal } \\
\text { - Families of civil servants must be enrolled by the respective offices } \\
\text { Migrant workers should present the evidence of enrollment while applying for } \\
\text { work permit }\end{array}$ \\
\hline
\end{tabular}




\begin{tabular}{|c|c|}
\hline $\begin{array}{l}\text { Contribution } \\
\text { amount }\end{array}$ & $\begin{array}{l}\text { - Annual premium provision with Family ( } 5 \text { members) as a unit } \\
\text { - NRs } 3500 \text { per family with additional NRs } 700 \text { for additional members } \\
\text { - Elderly (above } 70 \text { years) as a unit with a premium of NRs } 3500 \text { per year }\end{array}$ \\
\hline $\begin{array}{l}\text { Premium and } \\
\text { benefit packages }\end{array}$ & $\begin{array}{l}\text { - Services worth NRs } 100,000 \text { per family ( } 5 \text { members) with additional NRs 20,000 } \\
\text { with every additional member } \\
\text { - Service not exceeding NRs } 200,000 \text { per family } \\
\text { - Separate services worth NRs } 100,000 \text { for elderly members }\end{array}$ \\
\hline $\begin{array}{l}\text { Subsidy } \\
\text { provisions }\end{array}$ & $\begin{array}{l}\text { - } \\
\text { - } \text { Ulderly above } 70(100 \%) \\
\text { - Family members of seriously disabled, leprosy, HIV, MDR-TB patients }(100 \%) \\
\text { - Family members of Female Community Health Volunteers (FCHVs) }(50 \%) \\
\text { - The benefit of additional NRs } 100,000 \text { provided for the patients of cancer, } \\
\text { heart disease, kidney ailments, head injury, spinal injury, Sickle Cell Anemia, } \\
\text { parkinsonism, and Alzheimer's disease }\end{array}$ \\
\hline $\begin{array}{l}\text { Services and } \\
\text { exclusions }\end{array}$ & $\begin{array}{l}\text { - Liable for all preventive, promotive, curative (outpatient, inpatient, emergency, } \\
\text { surgery, medicines, medical aid equipment), diagnostic and rehabilitative, and } \\
\text { ambulance services } \\
\text { - Spectacles and other medical aids (White stick, crutches up to NRs } 1,000 \text { ) and } \\
\text { hearing device up to NRs } 5,000 \\
\text { - Plastic and cosmetic surgery except the treatment related to burns, seriously } \\
\text { disabled, cleft palate } \\
\text { - Artificial insemination } \\
\text { - Dental services except for dental extraction or abscess in the jaws and primary } \\
\text { - } \text { management of dental trauma } \\
\text { Ambulance service maximum up to NRs } 2000 \text {, only in emergency services }\end{array}$ \\
\hline $\begin{array}{l}\text { Eligible } \\
\text { providers }\end{array}$ & $\begin{array}{l}\text { - Both public and private can agree with the Board } \\
\text { Private providers must meet the pre-determined criteria before making a service } \\
\text { provider agreement }\end{array}$ \\
\hline $\begin{array}{l}\text { Service } \\
\text { utilisation } \\
\text { Process }\end{array}$ & $\begin{array}{l}\text { - The enrolled population must select first service contact points (FSCP) } \\
\text { - Only the public health institutions can be FSCP } \\
\text { - The Insured must visit the FSCPs in usual cases (OPD visits) } \\
\text { - They can visit any service providers in case of emergency services and referral } \\
\text { - Cashless system }\end{array}$ \\
\hline Reimbursement & $\begin{array}{l}\text { - } \text { Capitation fee } \\
\text { - Per case amount (Case-based) } \\
\text { - Fee for service } \\
\text { - The rate of reimbursement as per the agreement }\end{array}$ \\
\hline
\end{tabular}




\begin{tabular}{|c|c|}
\hline $\begin{array}{l}\text { Contract } \\
\text { termination } \\
\text { provision with } \\
\text { service providers }\end{array}$ & $\begin{array}{l}\text { - Non-renewal or informed termination with Board } \\
\text { - } \text { Failing to provide services under the contract } \\
\text { - } \text { Repeated breaching of contractual provisions } \\
\text { - } \text { Claims with forgery documents } \\
\text { - Failing to abide by other benchmarks and agreed terms of service }\end{array}$ \\
\hline Organisation & $\begin{array}{l}\text { - Health Insurance Board comprises of nine members (four De-facto and five } \\
\text { nominated) } \\
\text { - The autonomous nature of the Board has been imagined with its employees, } \\
\text { provincial offices, and flexibility to nominate the experts as required } \\
\text { - Provincial and local level health insurance coordination committees; claim review } \\
\text { and evaluation committee, grievance handling committee, service quality and } \\
\text { drug pricing sub-committee being envisioned }\end{array}$ \\
\hline Leadership & $\begin{array}{l}\text { - Government nominates the chairperson of the Board } \\
\text { Executive Director is appointed from the list of three possible candidates as } \\
\text { recommended by the recommendation committee }\end{array}$ \\
\hline $\begin{array}{l}\text { Financial } \\
\text { management }\end{array}$ & $\begin{array}{l}\text { - Different funding sources generate separate Health Insurance Fund } \\
\text { - All expenses of the Board are covered through this fund } \\
\text { - Administrative cost shall not exceed } 12 \text { per cent of the total budget of the Board } \\
\text { - Accounting and auditing as per existing laws } \\
\text { - Health Ministry can examine the Board's financial status at any time }\end{array}$ \\
\hline $\begin{array}{l}\text { Grievances } \\
\text { handling }\end{array}$ & $\begin{array}{l}\text { - Encourages grievances handling through mutual understanding and formation of } \\
\text { dispute resolution committee } \\
\text { - The insured have rights to file a complaint against service providers if they deny, } \\
\text { delay or degrade the service provision/quality } \\
\text { - The insured may appeal to the high court if they disagree with the board's decision }\end{array}$ \\
\hline
\end{tabular}

Source: Government of Nepal, 2017, 2019

\subsection{Coverage of NHIP}

The implementation of NHIP has gained strong political commitment since its inception. After the roll-out of NHIP in Kailali district in the fiscal year 2015/16, the programme was expanded to two additional districts (Baglung and Ilam) in the same fiscal year (Ghimire et al., 2019). The government in the budget speech of the fiscal year 2016/17 announced to allocate NRs 2.5 billion to expand the services to 25 districts across the country (Khanal, 2016), however, it was expanded to only 12 districts (Ranabhat et al. 2020). Similarly, the programme was expanded to 22 additional districts in the fiscal year 2017/18. Considering the public pressure and political commitments, the federal budget speech of 2018/19 aimed to scale up the programme throughout the country (Government of Nepal, 2018a), and NRs 6 billion was allocated for this purpose (Government of Nepal, 2018a). However, the programme was not expanded as per the plan despite adequate financial resources. The programme has been expanded in 58 out of 77 districts by the end of the fiscal year 2019/20. 
The NHIP services are provided through 347 health facilities across the country (Health Insurance Board, 2020). Figure 2 shows the expansion of NHIP by districts since its initiation in 2016. eight districts. The reason behind removing the co-insurance provision was the feedback from the insured as well as the health service providers. The insured argued that it was not rational to charge 15 per cent co-insurance in

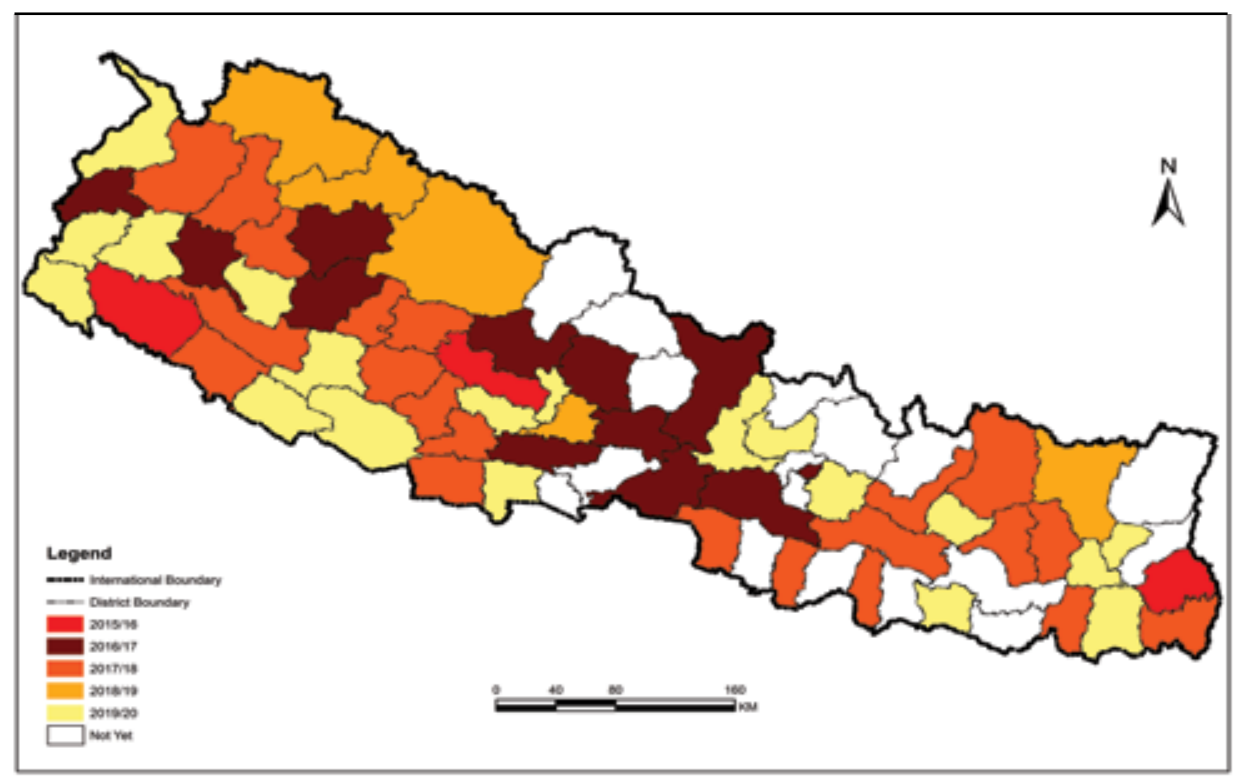

Figure 2: Expansion of NHIP by districts

During its initiation of NHIP in 2016, there was the provision of 15 per cent co-insurance in medicines. This provision was removed in 2017 after scaling up the programme in medicines since there is already a provision of ceiling of the benefits package. Likewise, the health service providers suggested removing this provision due to the administrative hurdle

Table 3: Number of insured beneficiaries under the social protection scheme, FY 2017/18 to 2019/20

\begin{tabular}{|r|l|r|r|r|}
\hline \multirow{2}{*}{ SN } & \multirow{2}{*}{ Categories } & \multicolumn{3}{|c|}{ Fiscal year } \\
\cline { 3 - 5 } & & $\mathbf{2 0 1 7 / 1 8}$ & $\mathbf{2 0 1 8} / \mathbf{1 9}$ & $\mathbf{2 0 1 9 / 2 0}$ \\
\hline 1 & MDR-TB & - & 135 & 1,097 \\
\hline 2 & Ultra-Poor & 252,776 & 315,488 & 299,430 \\
\hline 3 & FCHV & 8,820 & 13,978 & 29,889 \\
\hline 4 & Senior Citizen & - & 205,137 & 324,395 \\
\hline 5 & HIV & - & 1,530 & 6,849 \\
\hline 6 & Leprosy & - & 207 & 1,203 \\
\hline 7 & Null Disability & - & 13,039 & 34,542 \\
\hline & Total & $\mathbf{2 6 1 , 5 9 6}$ & $\mathbf{5 4 9 , 5 1 4}$ & $\mathbf{6 9 7 , 4 0 5}$ \\
\hline
\end{tabular}

Source: Health Insurance Board, 2020. 
associated with it. Later, several provisions on social protection mechanisms for the targeted population were included in the health insurance program. For instance, the elderly population above 70 years is eligible for full subsidies in premium that provides the health insurance coverage of NRs 100,000 (Government of Nepal, 2018a). Likewise, there are similar provisions for families of ultra-poor, null disability (red cardholders), leprosy, HIV, MDR-TB patients, however, family members of Female Community Health Volunteers (FCHVs) are eligible for 50 per cent subsidies in annual premium. On top of this, insurance coverage of NRs 100,000 is provided for patients of cancer, heart disease, kidney ailments, head injury, spinal injury, Sickle Cell Anaemia, parkinsonism, and Alzheimer's disease (Government of Nepal, 2019). Table 3 shows the number of insured beneficiaries under different categories of social protection in the past three fiscal years.

The analysis of the beneficiaries receiving social protection schemes in the past three fiscal years shows that the number of insured populations under the targeted population is in increasing trend except the ultra-poor. The decline of the ultra-poor population in enrollment of NHIP might be due to low satisfaction preventing the renewal of the policy.

The contribution amount paid by the state to the targeted population under NHIP is shown in Table 4. This shows that the contribution amount paid for the elderly population constitutes more than 81 per cent of the total contribution while that of the poor population is just 15.4 per cent. However, this data has not captured the contribution made by the provincial and local governments for providing social protection for the citizens. The recent report published by the National Planning Commission shows that 28.6 per cent of the Nepalese population are multi-dimensionally poor (Government of Nepal, 2018b). This figure will increase with the COVID-19 global pandemic and its associated economic challenges. Enrollment of all the targeted population will have a large numberoffinancialliabilitiesinthecomingdays.

The enrollment in health insurance was made voluntary when it was initiated

Table 4: Contribution amount (In NRs Million) of the targeted population in NHIP, FY 2017/18 to $2019 / 20$

\begin{tabular}{|r|l|r|r|r|}
\hline \multirow{2}{*}{ SN } & \multicolumn{2}{|c|}{ Categories } & \multicolumn{3}{c|}{ Fiscal year } \\
\cline { 3 - 6 } & & $\mathbf{2 0 1 7 / 1 8}$ & $\mathbf{2 0 1 8 / 1 9}$ & $\mathbf{2 0 1 9 / 2 0}$ \\
\hline 1 & Ultra-Poor & 73.43 & 158.64 & 173.98 \\
\hline 2 & FCHVs & 0.39 & 1.63 & 1.52 \\
\hline 3 & Elderly Population & - & - & 919.49 \\
\hline 4 & Disabled & - & - & 29.41 \\
\hline 5 & Leprosy & - & - & 0.75 \\
\hline 6 & HIV and AIDS & - & - & 6.43 \\
\hline 7 & MDR TB & $\mathbf{7 3 . 8 2}$ & $\mathbf{1 6 0 . 2 7}$ & 1.14 \\
\hline & Total & & $\mathbf{1 , 1 3 2 . 7 2}$ \\
\hline
\end{tabular}

Source: Health Insurance Board, 2020. 
in 2016 (Government of Nepal, 2017). The Health Insurance Act, 2017 made mandatory enrollment provision in NHIP. This provision demonstrates a broader political commitment on social protection in health with the provision of subsidies for the poor, disabled, elderly, and the patients requiring specific healthcare needs (Thapa et al., 2017). Furthermore, civil servants had to get enrolled in the NHIP based on progressive contribution in the premium amount (Government of Nepal, 2019). Despite these legal provisions, the enrollment in NHIP is relatively low. Only about 3.1 million (about $10 \%$ population) have been enrolled after the expansion of the programme in two-third of geographical area (Government of Nepal, 2020c). Furthermore, almost 0.7 million were enrolled through government subsidies $(22 \%$ of the total insured population) that includes 0.3 million ultra-poor and 0.3 million elderly population above 70 years (Government of Nepal, 2020b, 2020a), which indicates a poor attraction of the general public towards NHIP. Similarly, one-fourth of the insured population discontinued the NHIP policy (Subedi, 2019) that indicates a poor retention rate. The low attraction and retention in NHIP indicate serious challenges in increasing the risk pooling mechanism, which ultimately affects in the sustainability of the program.

Identification of poor population is another challenge. Targeting poor households is difficult because the criteria for eligibility may be hard both to define and to verify. Furthermore, there is no single defining characteristic of poverty, rather the criteria for eligibility tend to be multidimensional, and hence the process of identifying the poor is often controvertible (Karlan \& Thuysbaert, 2019). The process of identifying the poor in Nepal was heavily criticized in the past, as poverty identity card was occupied by the higher-classes rather than the actual poor people (Shahi, 2018). All the ultra-poor populations who have obtained the poverty identity card have not been enrolled in the NHIP. Similarly, the provision was subsidised for the ultra-poor population only, and such provision for other poor populations has not considered equity and social justice in social protection. Access to care, quality of care provided, and the attractiveness of the benefits package, and the offered financial protection are equally relevant to attract the non-formal sector (Vilcu et al., 2016). Thus, the progressive mechanism with quality of healthcare is important to ensure universal coverage by increasing the pool of insured population (Yates, 2015).

The mandatory enrollment of formal public sector like the civil servants, security forces, school teachers is important for increasing the risk pooling mechanism. The formal sector constitutes only about 15 per cent of the total national economy (Pokharel \& Silwal, 2018). However, this population group has not been enrolled in NHIP despite the mandatory provision (Government of Nepal, 2019). The mandatory enrollment provision for the formal sector can be made effective by intersectoral coordination among the concerned stakeholders. For instance, the standard operating protocol which guides enrollment in NHIP before the application for foreign employment has not been developed. Almost 400,000 applicants applying for foreign employment annually are still beyond the reach of NHIP (Government of Nepal, 2020b). The mandatory enrollment of families of people working in the formal sector and those going abroad for foreign employment through the endorsement and implementation of necessary legal arrangements could increase the mechanism of risk pooling. Likewise, the enrollment of the non-formal sector is yet another challenge in the country where a huge portion of the population works in the non-formal sector. 
The countries have adopted several models for enrolling the non-formal sector in health insurance program. For instance, Ethiopia has adopted a community-based health insurance scheme (Lavers, 2016), while some Asian countries like China, India, and Vietnam have adopted a partial subsidization to attract the non-formal sector.

The national health insurance programme covers the cost of the listed medicine, however, many health facilities often run out of these commodities. A nationwide survey in 2015 reported that more than 80 per cent of the primary health care centers (PHCC), which are also the first service contact points under NHIP were lacking basic equipment like weighing machines, thermometers, stethoscopes, blood pressure apparatus, and the light source. Likewise, only 14.5 per cent of the district hospitals and 4.4 per cent of PHCCs had reported the availability of all the 18 essential medicines during the time of the survey (Ministry of Health et al., 2015). This indicates the institutional-like uninterrupted availability of medicine and equipment, human resource in health, and health service delivery mechanism was not sufficient enough to implement the health insurance programme in 2016. Furthermore, 347 service contact points in 563 local governments and $2 / 3$ of the geographical area where the programme is being implemented is not sufficient to deliver quality services (Health Insurance Board, 2020). Besides, the compromised quality of health care could lead to poor retention in NHIP. The Ministry of Health should expand its regulatory role by defining minimal quality of care of all the levels and types of health facilities and regulate the procurement of medicines, medical equipment, and its supplies and availability by setting minimum quality criteria (Sharma et al., 2018). This can be done through the establishment of an autonomous quality assurance authority.

\section{Conclusion}

NHIP is one of the social protection programs in Nepal. The programme aims to reduce the financial burden in seeking healthcare by cost-sharing and cost-subsidy mechanism. It is contribution-based social protection where there is a cross-subsidy mechanism between low-risk and the high-risk, poor and the rich, elderly and the young population, and diseased and the healthy population. The programme has gained a strong political commitment from all the major political parties; however, improvements are needed in its implementation. The population who assume that they are on health risk or only the population who are eligible for receiving subsidies for enrollment are getting enrolled in NHIP. Thus, a large portion of the low-risk population is still outside the program. The financial sustainability of NHIP rests on increasing the pool of the lowrisk population. The low interest of the lowrisk population towards NHIP and the high drop-out rate even after getting enrolled has to be addressed immediately for the sustainability of NHIP.

The NHIP programme should focus on enhancing the quality of healthcare that could attract a larger number of populations. The quality healthcare services not only raise the new enrollment but also increase the retention rate. The existing number of first service contact points is not sufficient and need to be increased. A greater number of service contact points increases the access in the utilization of healthcare services provided by NHIP. Furthermore, the number of enrolled populations can be increased with inter-sectoral coordination with other line ministries and concerned authorities. Furthermore, there should be a separate authority to monitor the quality of healthcare services delivered from the health facilities. 


\section{References}

Anand, P., Hunter, G., \& Smith, R. (2005). Capabilities and well-being: Evidence based on the Sen-Nussbaum approach to welfare. Social Indicators Research, 74(1), 9-55. https://doi.org/10.1007/s11205-005-6518-z

Communist Party of Nepal (CPN). (2017). Manifesto of communist Party of Nepal: Election of House of Representatives and Provincial Council 2017 (Unofficial translation). Retrieved June 25, 2020, from http://cmprachanda.com/2017/11/8487

Devereux, S., \& Sabates-Wheeler, R. (2007). Debating social protection. IDS Bulletin, 38(3), 1-7. https://doi. org/10.1111/j.1759-5436.2007.tb00363.x

Drucaz, K. (2016). Social inclusion and social protection in Nepal (Deakin University). Retrieved from http://dro.deakin.edu.au/ view/DU:30089153

Drucza, K. (2018). The politics behind social protection in Nepal. Asian Journal of Comparative Politics, 3(4), 311-335. https:// doi.org/10.1177/2057891117734652

Ghimire, P., Sapkota, V. P., \& Poudyal, A. K. (2019). Factors associated with enrolment of households in Nepal's national health insurance program. International Journal of Health Policy and Management, 8(11), 636645. https://doi.org/10.15171/ijhpm.2019.54

Government of Nepal. (1992). Children's Act 1992.

Government of Nepal. (2015). The Constitution of Nepal, 2015.

Government of Nepal. (2017). Health Insurance Act (Unofficial Translation).

Government of Nepal. (2018a). Budget Speech 2018/19 (Unofficial Translation).
Government of Nepal. (2018b). Nepal multidimensional poverty index 2018: Analysis towards action. https://www.npc. gov.np/images/category/Nepal_MPI.pdf, accessed on 20 September 2020.

Government of Nepal (2019). Health Insurance Regulation (Unofficial Translation)..

Government of Nepal. (2020a). Budget speech 2020/21 (Unofficial Translation). https:// mof.gov.np/en/archive-documents/budgetspeech-17.html?lang $=$ accessed on 21 September 2020.

Government of Nepal. (2020b). Economic survey 2019/2020 (Unofficial Translation). In Ministry of Finance. https://mof.gov. $\mathrm{np} /$ uploads/document/file/Economic Survey_2076-77.pdf accessed on 12 September 2020.

Government of Nepal. (2020c). Health insurance doard dashboard. http://dashboard.hib.gov. $\mathrm{np}: 81 /$ accessed on 16 September 2020.

Health Insurance Board. (2020). Sharing meeting with external development partners on health insurance programme Paper Presented at Situation Analysis of Health Insurance Programme, Kathmandu.

ILO. (2020). Towards universal health coverage: Social health protection principles. In Development in Practice. https://doi. org/10.1080/09614520701469435

ILO. (2002). Extending social protection in health through community based health organisations: Evidence and Challenegs.

Karlan, D., \& Thuysbaert, B. (2019). Targeting ultra-poor households in Honduras and Peru. World Bank Economic Review, 33(1), 63-94. https://doi.org/10.1093/wber/lhw036

Khanal, G. N. (2016). Will it work? Republica Daily. https://myrepublica.nagariknetwork. 
com/news/will-it-work/ (June 15, 2015) accessed on 15 September 2020.

Khanal, G. N. (2018). Conditional cash transfer policies in maternal health service utilization in Nepal: Analysis of safe delivery incentive programme (Aama Surakshya Karyakram) using Kingdon's multiple streams framework. International Journal of Health Planning and Management, 34(1), e131e141. https://doi.org/10.1002/hpm.2691

Knaul, F. M., González-Pier, E., Gómez-Dantés, O., García-Junco, D., Arreola-Ornelas, H., Barraza-Lloréns, M., ... \& Frenk, J. (2012). The quest for universal health coverage: Achieving social protection for all in Mexico. The Lancet, 380(9849), 1259-1279. https:// doi.org/10.1016/S0140-6736(12)61068-X

Lavers, T. (2016). Social protection in an aspiring 'developmental state': insurance in Ethiopia (No. 71). Manchester, UK.

Michielsen, J. J. A., Meulemans, H., Soors, W., Ndiaye, P., Devadasan, N., De Herdt, T., ... \& Criel, B. (2010). Social protection in health: The need for a transformative dimension. Tropical Medicine and International Health, 15(6), 654-658. https://doi.org/10.1111/ j.1365-3156.2010.02529.x

Ministry of Health and Population. (2018). Nepal national health accounts 2012/13-2015/16. http://www.searo.who.int/nepal/documents/ nepal_nha_2012_13_2015_16_mohp_ june_2018.pdf accessed on 26 September 2020.

Ministry of Health, New ERA, Nepal Helath Sector Support Programme (NHSSP), \& ICF. (2015). Nepal health facility survey 2015. In Nepal Ministry of Health. https:// dhsprogram.com/pubs/pdf/SPA24/SPA24. pdf accessed on 18 August 2020.

Niroula, G. (2018). Trends and prospects of social security programme in Nepal. Nepalese Journal of Insurance and Social Security, 1(1), 73-85. https://www.nepjol.info/index. php/njiss/article/view/29864 accessed on 24 August 2020.

Pokharel, R., \& Silwal, P. R. (2018). Social health insurance in Nepal : A health system departure toward the universal health coverage. International Journal of Health Planning and Management, 1-8. https://doi. org/10.1002/hpm.2530

Ranabhat, C. L., Kim, C. B., Singh, A., Acharya, D., Pathak, K., Sharma, B., \& Mishra, S. R. (2019). Challenges and opportunities towards the road of universal health coverage (UHC) in Nepal: A systematic review. Archives of Public Health, 77(1), 1-10. https://doi.org/10.1186/s13690-0190331-7

Ranabhat, C. L., Subedi, R., \& Karn, S. (2020). Status and determinants of enrollment and dropout of health insurance in Nepal: an explorative study. Cost Effectiveness and Resource Allocation, 18 (40), 1-13. https:// doi.org/10.1186/s12962-020-00227-7

Shahi, N. (2018). Preying on poor people's ID. Retrieved from cijnepal.org.np/preying-onpoor-peoples-id/\%0Aadmin accessed on 21 August 2020.

Sharma, J., Aryal, A., \& Thapa, G. K. (2018). Envisioning a high-quality health system in Nepal: if not now, when? The Lancet Global Health, 6(11), e1146-e1148. https://doi. org/10.1016/S2214-109X(18)30322-X

Stroermer, M., Fuerst, F., Rijal, K., Bhandari, R., Nogier, C., Gautam, G. S., ... \& Sharma, S. (2012). Review of Community-based Health Insurance Initiatives in Nepal. http://www. healthinternetwork.com/providingforhealth/ countries/2013_04_Nepal_CBHI_GIZ_ report.pdf accessed on 13 July 2020. 
Subedi, S. R. (2019). Multi-billion-rupee health insurance scheme in crisis. Republica Daily website: https://myrepublica. nagariknetwork.com/news/multi-billionrupee-health-insurance-scheme-in-crisis/ accessed on 14 June 2020.

Tejuoso, O., Alawode, G., \& Baruwa, E. (2018). Health and the legislature: The case of Nigeria. Health Systems and Reform, 4(2), 62-64. https://doi.org/10.1080/23288604.20 18.1441622

Thapa, G., Aryal, A., \& Maru, D. (2017). In Nepal, health insurance for all. Health Affairs website: https://www.healthaffairs.org/ do/10.1377/hblog20171027.743636/full/ accessed on 5 June 2020.

United Nations. (1948). United Nations Human Rights Declaration. https://www.ohchr. org/EN/UDHR/Documents/UDHR_ Translations/eng.pdf accessed on 16 August 2020.

Vilcu, I., Probst, L., Dorjsuren, B., \& Mathauer, I. (2016). Subsidized health insurance coverage of people in the informal sector and vulnerable population groups: trends in institutional design in Asia. International Journal for Equity in Health, 15(165). https://doi.org/10.1186/s12939-016-0436-3

WHO, \& The World Bank. (2017). Tracking universal health coverage 2017: Global Monitoring Report. In World Health Organisation. https://doi.org/ISBN 978-924-151355-5

Witter, S., Khadka, S., Nath, H., \& Tiwari, S. (2011). The national free delivery policy in Nepal: Early evidence of its effects on health facilities. Health Policy and Planning, 26(SUPPL. 2), 84-91. https://doi. org/10.1093/heapol/czr066

Yates, R. (2015). Universal health coverage: progressive taxes are key. The Lancet,
386, 227-229. https://doi.org/10.1016/ S0140-6736(15)60868-6 